\title{
A Brief Analysis on the Changes of Princess Image in Disney Movies
}

\author{
Yu Zhang \\ Foreign Language Department \\ The Engineering and Technical College of Chengdu University of Technology \\ Leshan, China
}

\begin{abstract}
This paper aims at summarizing and generalizing the images of Disney princesses and analyzes the reasons for their changes, from the development of feminism, the increasing status of the black and so on. Through these analyses, readers can see some parts of American social development. This paper first gives the introduction to the developing history of Disney, the influence of Disney Princess's movies, the development of feminism, and then analyzes the types of Disney princesses and the reasons for their changes. It is easy to see that Disney takes active actions and measures in face of the development of American society. Hence through this paper, people can obtain more perspectives of observation when watching movies and have deep thoughts instead of only for entertainment.
\end{abstract}

Keywords-Disney movies; changes of princesses; feminism; social development

\section{INTRODUCTION}

With the dramatic development of the movie business, animated movies attract more and more attention around the world. Through unremitting efforts, Disney always maintains the leader in animation industry. Through a tortuous journey, Disney is not just a name anymore, and has become a glorious plant for the generation of animation and a kind of profound cultural concept. [1] Princess movies, the genre movies of Disney, have become one of the symbolic movies of Disney. The Walt Disney Company, which keeps pace with the times, gives new connotation to its movies and makes its animated characters more and more expressive, especially the images of its princesses. Disney is beginning to break through its traditional thinking pattern and makes its characters more multilevel, diversified and exquisite.

From the first princess-Snow White in 1937 till now, Disney has brought many classical princesses to the world, for example, Cinderella, Belle, Elsa and so on. These images of princesses influence the people all over the world, especially girls who always have princess complex. To some extent, Disney is a mirror of times, its princesses are different and changing with the times, and every princess has her own characteristics of the times and the cultural identities of her time. To this phenomenon, there are also some scholars researching this, most of whom analyze the reasons for their changes from the aspect of feminism and the improvement of women. It is true that beautiful princesses changed from the type of waiting for prince's redemption to self-salvation. [2]
But it is only one of the reasons that lead to these changes, so in this paper, more perspectives of observation will be applied to analyze the reasons that cause the Disney princesses more and more diversified than before, for example, the aspect of American people's national identity. Analyzing relevant books and literatures, watching Disney princess movies, searching related information, the changes and the reasons will be briefly illustrated. From different angles, this paper will analyze the changing times that Disney princesses reflect and Disney's success factors, providing audiences with a perspective of observation.

\section{GENERAL INTRODUCTION TO DISNEY AND PRINCESS MOVIES}

Globalization becomes more and more universal and people get in touch with the world. In modern society many people have pressure; under pressure, people begin to find ways to relax, so watching movies becomes a good way. In numerous animated movies, Disney animated movies undoubtedly are the second to none. After a prolonged endeavor, Disney's movies present a multicultural perspective and advanced technologies.

\section{A. The Development of Disney}

The Walt Disney Company was established by Walt in 1926. "It all started with a mouse", this was what Walt Disney, who was an animation genus born in 1901 in Chicago, always said to his employees. As Li Sida points out in his book, Disney's success is a legendary story in Hollywood history [3]. Walt Disney, who came to Hollywood from his hometown Kansas when he was 22 years old, stood his ground and pursued his dream. With enthusiasm and perseverance, he stood his ground with the help of the comedy series of Alice. Then he seized the chance of the appearance of sound film and created the first audio cartoon in the world-Steamboat Willie, which made him well-known. Indeed Mickey Mouse in Steamboat Willie let Disney's career start, made him won the title of "the father of Disney" and enjoys high reputation in the world. Disney Company strode on a new stage in 1932, for it launched the first color music cartoon in the world-Flowers and Trees which won Walt the first Oscar award for best cartoon. In 1937, despite the nay-saying, Disney created the first animated feature movie Snow White and the Seven Dwarfs in the world. The success of this movie made Walt realized that despite that the short movie still had some market, the prospect 
of the feature movie was more promising, and so Disney must grasp this new developing orientation. Then after a record profit, Disney Company put all its energy into the second feature movie Pinocchio. But when Disney Company advanced its business smoothly, the Second World War broke out, which made animation industry very stagnant. The loss of overseas markets made Disney's financial situation deteriorate, and as a result, Disney's inner employees began unsettled, letting Disney get into hot water. After a period of chaos, Disney found its new field, in Song of the South, Disney combined live actors with animated figures, which proved to be a success. Disney said in his memoirs, "only by making movies multiple can we save ourselves, that's the reason what makes me realize that I can't stick to make cartoons only and turn to live-action movies.

During the seventeen years after 1950, Disney's featurelength animated movies entered a new prosperous period, lunching many influential movies such as Cinderella, Alice in Wonderland, and Sleeping Beauty and so on. And in 1955 Disney founded the first Theme Park in the world-Disneyland which influences many people and is built in many countries now. For example, in 1998 Disney Company announced that it would cooperate with Hong Kong Special Administrative Region government in building Hong Kong Disneyland, which is proved to be a great success.

But with Walt Disney's death in 1966, Disney Company came into a downturn and then the internal struggle arose. What's worse, Miller's wrong leadership made Disney have a sizable loss. Fortunately, the return of little Roy let Disney enter into the recovery period, and he found a new leader Eisner who brought about Beauty and Beast and The Little Mermaid that caused a great sensation in the world.

With the rapid progress of science and technology, animation industry entered the era of CG (Computer Graphics) in the 1980s. Faced with tremendous pressure of market competition, the digital Disney started a new journey. In 2006, the new CEO Robert took office, and the first thing he did after his assumption of duty was acquiring Pixar with huge sum of money, which afterward showed to be a right choice, because it helped Disney entered into a wider market. The following movies, such as Cars, Ratatouille, and Dolly and so on, moved audiences with unique angle of view and grew rapidly in popularity. And Frozen is also a big success of Disney Company. It is true that with continuous endeavor Disney became more and more influential and popular, and its superb technology combined with abundant movie plots and various cultures makes Disney be the leading position.

\section{B. The Influences of Disney in the World}

Disney influences the world far more than in movies' aspect, and makes its way from plush toys, video tapes and clothing to children readings all over the world. Many people accompanied by Disney movies and readings always give high praise to Disney. The development of Disney propels the progress of the whole animation industry, for it plays an exemplary role for other countries' animation industry. Disney plays another role that is the disseminator of American culture, for it has a happy and healthy concept and spreads the values of respect and equality. [4] Nowadays Disneyland, the landmark building of America, attracts many people and has gained numerous commercial values for Disney. Under the lead of Disney, many European countries' animators seize the opportunity to develop animated movies and popularize them to the world. Disney always devotes itself to producing movies with best quality and rich connotation, so out of question its future will be excellent.

\section{The Introduction to Disney Princess Movies}

Disney princess movies are one of the trademarks of Disney Company. There are twelve Disney Princess Movies till now, including Snow White and the Seven Dwarfs (1937), Cinderella (1950), Sleeping Beauty (1959), The Little Mermaid (1989), Aladdin (1992), Beauty and Beast (1991), Pocahontas (1995), Mulan (1998), The Frog Princess (2009), Tangled (2010), Brave (2012) and Frozen (2013). These movies make money from the whole world through the classical princesses whose influence and reputation stand in the first place without dispute. From the appearance of the first feature length animation-Snow White and the Seven Dwarfs in 1937 to the hottest 3D animation movie-Frozen in 2013, crossing almost eighty years, the thirteen classical princess movies of Disney Company brings a lot of profit and prestige to Disney.

Being widely spread, Snow White and the Seven Dwarfs, which has great significance and special value to Disney and animation movie history, has become a synonym for moral norms and the measurement of beauty and ugliness and good and evil. It instantly gained much popularity among its audiences after it appeared on the screen, and helped Walt reached the summit of his career. The movie Cinderella, released in 1950, earned a good box office and got the best Musical Picture of Golden Male Award in Berlin Film Festival. And after the success of Cinderella, Disney sequentially launched Cinderella II Dreams Come True and Cinderella III Time Magic, which annotate the classic love story of princess and prince in different angles. Sleeping Beauty, another traditional love story of princess and prince, was launched in 1959, but this time, this kind of traditional pattern was not fully accepted by people again because of the movement of feminism and society. The Little Mermaid, however, became a representative movie of Disney and was praised by audiences, because it not only brought people the ambience of the sea but also brought people the awareness of feminism, it endowed animation with new sense of the time and new national individuality. [5] The movie Beauty and the Beast was released in 1991 and won the first Oscar for Walt Disney for Best Original Score, and also is the only animated movie ever nominated for the Best Picture Academy Award. The homonymous theme song of the movie, Beauty and the Beast, is lauded as "The Acme Movie Music of Disney". World famous animated movie Mulan popularized Chinese culture to the world, and exploded in popularity after more than five years' elaborate preparation, which showed Disney began to be diversified and international. The subsequent princess movies such as The Frog Princess and Rapunzel received heated extolling. The popular movie Frozen in 2013 also attracted many people, and even influences girls around the world now. It is necessary to mention that the total box-office of Frozen 
reached 1.072 billion dollars, and the heroine, Elsa, was imitated by many people.

There are not only fairy tales but also moral sense in Disney princess movies, and they accompany many people's growth. They teach us how to love and feel the truth and emotion. The magic Kingdom they knit is the heaven for many people's dreams, and the joy and laughter they bring let people no longer feel lonely and cold. Although these movies don't have any continuity between each other, the changes of these princesses have something related to the social background, for the changing route of them is visible for people to see.

\section{ThE ChANGES OF THE DISNEY PRINCESSES' IMAGES}

The Images of Disney princesses are very diverse, since the first Disney princess-Snow White appeared in mass media in 1937, the Walt Disney Company shaped many other classic images of princesses, but some of them were not the traditional blond white girls any longer, and the characteristics of them also changed a lot. How they changed and the types of their changes will be illustrated later in this part.

\section{A. From the Type of Waiting for Redemption to Self-salvation}

Firstly, there are two types of Disney princesses. One is the type of waiting for redemption, which means that princesses of this type always wait for others to rescue themselves and for them love is the only hope. They are always so passive and weak that they need princes to save them. The other type is the princesses that have awareness of independence and initiative. [6]

For the first type, Snow White is a very classic example. The beautiful Snow White was a beautiful girl who was always bullied by the queen. She was so innocent that she was cheated by the queen over and over again, and she had no way but to be protected by the seven dwarfs and wait for the prince to rescue her. Active men rescued the passive women, which was the final end of the movie, and that's true of Cinderella and Sleeping Beauty. These stories convey the passivity and wait of the women to the audiences. In these movies, the heroes always commanded all the power. For example, the heroes in Snow White, Cinderella and Sleeping Beauty were all princes who had the ability to rescue the suffered princesses. Snow White was completely in the state of reaction, even the theme song of her- "Someday my prince will come" was full of blind optimism and passive waiting. Of course, the existence of Snow White is complied with the need of history, which will be illustrated in the third part of this paper. The fact is that although the boring healing princesses attracted many people who underwent traumatic period, the typical type of princess in peaceful age. Sleeping Beauty was the end song of the aesthetic idea of the age. Since then, the images of princesses quietly changed.

After Sleeping Beauty, Disney hadn't touched the topic of the princess for a long time until The Little Mermaid in 1989 and Beauty and the Beast in 1991 made an appearance in public. They made Disney enter its renaissance and brought good luck to Disney Company. The little mermaid Ariel was the first princess who bravely pursued love. She's a little rebellious and no longer complains, but her rebellion got a lot of praise because at that time Feminism had moistened something silently. And the critics said that this was the trend of the development of Disney princesses, and Disney Company indeed did so. The princesses at that time were more close to real life, for they were no longer noble and perfect only, but began to be like a girl who had some little defects. The little mermaid changed into a normal adolescent rebellious girl from the image of perfect belle. In order to chase after a vigorous love, she secretly exchanged her beautiful voice for two big long legs. Afterwards the Belle in Beauty and the Beast embodied the independent and initiative sense of female, for she was totally not afraid of the terrible likeness and rude behaviors of the beast. She was always actively looking for knowledge, adventures and the good of her and her father. Beauty Belle showed audiences a princess who needn't to rely on man and dominated her own destiny actively, which was also the feature of Rapunzel in Tangled, Merida in Brave, especially Elsa and Anna in Frozen in 2013. The theme of Brave and Frozen is not the love between male and female but the love between mother and daughter or sisters, and the image of the heroes in these movies is becoming less important and even wicked. Princesses don't need princes any more, and they are becoming more and more independent and excellent, who know how to rescue themselves and pursue their dreams. [7] In these movies, although the stories were also about princesses, the ideas about independence and the initiative combined with a variety of modern thoughts made these "new fairy tales" more distinctive and attractive.

\section{B. From White Race Only to Multiple Nationalities}

In the 1950s, the discriminations to ethnic minorities, women, gays and lesbians were not rare. But through all kinds of social movements such as African-American Civil Rights Movement, Anti-war Movement, the Second-wave Feminism and so on, America had a qualitative leap in democracy. [8] As one of the important movements of the civil rights movement, Racial Equality was branded in the minds of people, and Disney's princess movies represented the improvement of the status of nationalities besides the white race.

In the early Disney princess movies, the princesses were all Anglo-Saxon race no matter Snow White, Cinderella or Aurora in Sleeping Beauty. Until the emergence of the little mermaid, the heroine was not just blond Anglo-Saxon race, for its well known that the little mermaid was the unacceptable Ginger race in white society. In the decades since, Disney had created many ethnic minorities, such as the Arabian princess Jasmine in Aladdin, the Indian princess Pocahontas in Pocahontas and the black princess Tiana in The Frog Princess. And the heroine in Mulan in 1998 stood Chinese women's characters and strength, which meant that Disney was spreading all over the world. The Princess Tiana was the first black princess in Disney animation history, which was as meaningful as the entering office of Obama. The Frog Princess not only reflected the American Dream but also hailed to the optimistic and positive black in New Orleans. [9]

The new skins of Disney princesses, especially the emergence of the African princess, aroused much attention and discussion. To this, there were two parties. Some people thought that the way in which Disney shaped its heroines didn't 
conform to the public's definition of beauty. Some people, on the other hand, held the opinion that the inherent gender role specification should be broken already. It is known that Disney princesses play an important role in American culture, so the images of them would play a key role in setting up the standard of beauty. There was a public opinion put forward as the single and stereotyped roles were not conductive to the healthy development of children. What the images of Disney princesses should be like has no correct answers, but it is obviously that changing along with the changing times is always a right choice.

\section{From the Image of Traditional Women to Modern Women}

In traditional America, women should have to be laborious and can do housework, enjoying their female identity elegantly, raising children and caring husband's living and eating at the same time. [10] In Disney's early movies, love was the only hope for princesses who had a kind heart and beautiful appearance and would always find love and get married when they were in a certain age. Snow White and Cinderella both had the ability of cooking, for its undeniable that this kind of image was complied with the demand of society at that time. They didn't have their own dreams, and they gave up their work and treated love and marriage as their career. However, with the change of women's status and roles, princesses in Disney movies started to change.

Influenced by the third wave of feminism, the little mermaid, Ariel changed a lot in character. She was no longer weak and knew nothing about what's going on in the world, but became an independent with a rebellious spirit of modern women. Belle in Beauty and the Beast loved reading, which was the privilege of men at that time. And the later heroines, Jasmine, Mulan, and Pocahontas and so on, all had their own thoughts and independent selves. In these movies, princesses were no longer just beautiful women or men's appendage. For some princesses, love was only the attachment in the process of their seeking for their aspiration and dreams. As for other princesses, such as Mulan, Merida and Elsa, there's even no love in their stories, which is the most contemporary style of Disney Princesses. And they took their future by themselves. They were persistent, selfless and diligent. For example, the first black princess Tiana, her dream was to open a restaurant of her own, and she struggled for her dream at the beginning of the movie. Merida in Brave was so distinctive that she went against her father's order to get married. Marriage and family are less important for female life, or in other way, they became less urgent of women. Nowadays women can choose like men what they really want to do, such as when and how to get married, or even no marriage life. This is the natural consequences of equality between men and women, though there is still a lot to be done.

\section{REASONS FOR THESE CHANGES IN PRINCESS MOVIES}

Various princesses with different personalities are important roles in Disney animated feature movies. And in the process of combing the 100-year history of Disney, the audiences can feel its positive role in terms of Feminism, National Identity and the Black Movement. Disney can be regarded as a mirror of times, which witnessed the social development of America.

\section{A. The Development of Feminism and the Improvement of Women's Status}

In 1937, Disney's first feature length animation appeared in public, when the United States just suffered from the Great Depression; so at that time people needed such a movie which was full of love and had a cheerful ending to comfort their hearts. Walt once said that he grasped the key because he had the compassionate dwarfs and a happy ending. It's true that Snow White and the Seven Dwarfs and Cinderella were very successful, but the failure of Sleeping Beauty warned Disney that they should change.

The United States in 1960s was filled with movements such as Feminism, the Hippie Movement and a variety of postmodern cultures. [11] The first wave of the Women's Liberation Movement was at the end of the $19^{\text {th }}$ century, the focus debate of it was to require gender equality and call for civil and political rights. The movement, against aristocratic privilege, polygamy and gender inequality, and the most important goal of which was to strive for the equivalence of household labor and social labor and the equal rights for politics, was often called as "the feminist movement". The second wave of feminism was from 1960s to 1970s, it is believed that the second women's liberation movement firstly originated in the United States. The basic tone of it was to eliminate the unfair phenomenon of different payments to same work for men and women. The second feminist movement brought another result that was the rise of the studies and research of gender and feminism. [12] Therefore, there are various schools of feminism, but the fundamental purpose of them is to eliminate discrimination and oppression of women. So Sleeping Beauty launched in 1959 represented the end song of aesthetic thoughts and moral sense of an age. Because of the influence of Feminism, Disney had not produced movies about princesses, but in 1989 the returning of Disney princess---Ariel bought Disney Princesses back to audiences with a fresh flavor of Feminism. But it was undeniable that decades of feminism had already been branded deeply in people's hearts. The demand of the equality of women and men had been called for in education, employment, marriage and so on. [13] So at that time Disney began to change the types of princesses, who began to be more normal and independent. New Feminism endowed Disney princesses with new connotation. For example, Rapunzel started her adventure to seek her identity which also meant to seek female identity. After eighty years' change, men finally descended from the "savior" to the "black hand", which meant that women finally realized that suppression of their liberation came from hypocritical men. So sometimes women may don't need men anymore. And Disney follows this trend of Feminism to change its images of princesses.

\section{B. The Awakening of National Identity and the Improvement of the Black's Status}

Nowadays in America, if someone dares to make any racial discrimination or gender discrimination deeds, they will be immediately submerged in overwhelming criticism. And recently National Identity has been an active issue which is 
concerned and studied by ethnologists, psychologists and sociologists at home and abroad. Wang Fuxin and Yi Lianyun hold that National Identity has great political significance, and the study of the problems of National Identity plays an important role in promoting national unity and building a harmonious society. [14] National Identity has influenced many people and the status of the black or other nationalities has improved a lot. Actually these were achieved through all kinds of civil movements in just a few decades after the Second World War. In 1950s' American society, the discrimination to ethnic minorities, women and homosexuals is not rare. But a lot of movements such as Awakening of National Identity, the Civil Rights and the Black Movement, brought a jump in democracy in America. And this is the victory that countless people strived at the cost of blood, sweat and tears. The famous black civil rights leader Martin Luther King was unfortunately murdered, and it's their struggle that deepened democracy. It's necessary to mention the taking office of president Obama gives a lot of people confidence. So it's no wonder that Disney always follows the footsteps of time so that it won't be out of time. The skins of Disney princesses in its movies are no longer just white, such as Snow White, Cinderella and Aurora in Sleeping Beauty, there are black princess in The Frog Princess, yellow princess in Aladdin and ginger princesses in The Little Mermaid, which shows the Disney's political consciousness. Only by following time can Disney find its way to keep in style and be the leader of animation industry.

\section{Economy and Culture}

As the development of economy and society, we are living in a globalized world, which means people all over the world can communicate with each other. In the process of going to be global, Disney animated movies not only face the challenge of the computer technology of 2D, 3D and 4D movies, but also the competition with other companies. If Disney wants to gain a foothold in the global movie market, it should keep the pace of the times. And the overseas market is another valuable market which can bring Disney lots of profits. China inevitably becomes a big market for many foreign countries, so Disney made Mulan which is a classic movie showing the culture of China. And besides that, they merged the Chinese traditional culture and the concept of American spirit together, making its cultural products successfully come across the geographical barriers of culture transmission and achieving the global spread of American culture. And the economy makes making movies begin a profitable market no matter in America or other countries. For example, the box office of Frozen in 2013 is more than one billion dollars. The pursuit of equality also deeply influences Disney, and the cultural exchange makes Disney become more and more globalized, and the technology of computer animation making of Disney is becoming superb.

\section{CONCLUSION}

This paper analyzes the history, the changes of Disney princesses and the reasons for their changes, which shows the development of some civil rights of America, such as the rights of women, blacks and nationalities. As Disney is known for being pioneers in the industry of animation, and produces many outstanding movies with the leading computer technology, each of its new reform is accompanied by an influential work. Its technology makes Disney a powerful animation kingdom, but the key reason for the success of Disney is its keeping closely to the changing times and cultures. For example, when the feminism appeared in public and influenced people all over the world, Disney then changed the images of princesses, which also showed the development of Feminism in return. Disney always made its countermeasures according to the development of America, which is an example for many other companies to follow.

It's always the truth that creativity is the key to succeed. Disney's success sets a good example for others, and we have to admit that compared with Disney animated movies, Chinese animated movies have many defects. So it's time to change and create something special for China which has a long history. Disney's related products such as readings, toys and video types make much money for Disney Company. Therefore, through this paper, people can gain more perspectives of observation when watching movies and have deep thoughts instead of only for entertainment. In the future, it may be common for people all over the world to learn about cultures in the world in such changing world. And it's necessary for any business companies to follow the steps of the page of time.

\section{ACKNOWLEDGMENT}

I extend my sincere gratitude to a number of people who have contributed to this paper. Without their help, this paper would not have been accomplished. Here my first acknowledgements should go to all those authors whose books I have consulted and borrowed from, and with the knowledge learnt from them can I have the ability to write this paper. My heart-felt gratitude also goes to my friends and colleagues for their valuable suggestions and professional guidance, they have benefited me a lot, their constant help and kind encouragement have led me to finish this paper.

\section{REFERENCES}

[1] Capodali, Bill and Lynn Jackson. The Disney Way: Harnessing the Management Secrets of Disney in Your Company. DBA, 2007.

[2] Li Guanghua. "Disney film princess growth." Chinese and foreign entrepreneurs, vol.16, 2015, pp: 270.

[3] Li Sida. Disney Animation Art History. Beijing: Tsinghua University Press, 2009.

[4] Wang Yunbo. "The cultural connotation of Disney animated film." Northwest Normal University, 2010.

[5] Towbin, Mia Adessa. "Images of gender, race, age, and sexual orientation in Disney feature-length animated films." Journal of Feminist Family Therapy, vol. 15, 2002, pp: 19-44.

[6] Yang YF. "A new feminism-on the application of deconstruction in the Disney princess series." Journal of Xi'an International Studies University, vol.1, 2015, pp: 93-96.

[7] Wang Zhujun. "From the 'Frozen' to talk about the changes in the role of women in Disney in recent years." Popular Literature, vol. 12, 2014, pp: 193-194.

[8] Duncan, Russell and Joseph Goddard. Contemporary America. Beijing: China Renmin University Press, 2009.

[9] Gehlawat, Ajay. "The strange case of the princess and the frog: passing and the elision race." Journal of African American Studies, vol. 14, 2010, pp: 417-431. 
[10] Cai Yongliang. He Shaobin. American Civilization. Shanghai: Shanghai Sanlian Bookstore, 2010.

[11] Li Jianming, Yang Lingxia. The Multiple Features of American History . Beijing: Peking University Press, 2010.

[12] Banks, Kira Hudson. "The impact of feminist attitudes on the relation between racial awareness and racial identity." Sex Roles, vol. 70, 2014 pp: 232-239.

[13] Judith Butler, Song Sufeng. Sex Trouble: Female Trouble and Identity Subversion. Shanghai: Shanghai Sanlian Bookstore, 2009.

[14] Wang Fuyin, Yi Lianyun. On the concept of ethnic identity and its level. Qinghai Ethnic Studies,vol. 22, 2011, pp: 36-38 